\title{
Observed Income Velocity of Money: A Misunderstood Issue in Monetary Policy
}

\author{
LEONALL C. ANDERSEN
}

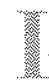

$\mathrm{N}$ recent years there has been considerable debate in the literature on economic stabilization and in policy discussions regarding the ability of monetary authorities to achieve a desired growth of nominal income by controlling the growth of the money stock. This debate concerns the predictability of the response of the growth of income to a change in the growth of money. A frequently cited piece of evidence in support of the view that this response is not very predictable has been observed movements in the income velocity of money - nominal income divided by the money stock.

This use of income velocity is based on a common postulate in monetary theory that holders of money balances desire, at a given point in time, a certain ratio of money to income and equilibrium income velocity is the inverse of this desired ratio. As such, velocity changes are postulated to depend on those economic and other factors influencing desired money balances. A common practice is to use observed velocity as a proxy for the demand for money. A change in observed velocity is interpreted as an opposite change in desired money balances relative to income.

Many analysts make monetary policy recommenda" tions to achieve desired growth in income in terms of a planned growth of money relative to predicted movements in velocity. In simple form, a percent change in nominal income $\left(\% \Delta Y_{\mathrm{t}}\right)$ is defined as the percent change in the nominal money stock $\left(\% \Delta \mathrm{M}_{\mathrm{t}}\right)$ plus the percent change in velocity $\left(\% \Delta \mathrm{V}_{\mathrm{t}}\right)$.

$$
\% \Delta \mathrm{Y}_{\mathrm{t}}=\% \Delta \mathrm{M}_{\mathrm{t}}+\% \Delta \mathrm{V}_{\mathrm{t}} \text {. }
$$

According to this identity, there is a predictable response of income to a change in money if the percent change in velocity is constant, or if the percent change in velocity is variable, but predictable.

Based on observed movements in velocity, economists have reached vastly different conclusions re garding the predictability of the response of income to a change in the money stock. For example, Milton Friedman and Anna Schwartz, in their study of the monetary history of the United States from 1867 to 1960 , concluded that ${ }^{1}$ ${ }^{1}$ Milton Friedman and Anna Jacobson Schwartz, A Monetary
History of the United States, 1867-1960 (Princeton, New Jersey: Princeton University Press), 1963, p. 679.
The velocity of money, which reflects the moneyholding propensities of the community, offers another example of the stability of basic monetary relations.

They also concluded that

Changes in the behavior of the money stock have been closely associated with changes in economic activity, money income, and prices. ${ }^{2}$

Other analysts have argued that the income velocity of money is so variable and unpredictable that changes in the money stock are not useful as an indicator of the thrust of monetary policy actions. Still others have emphasized the observed procyclical behavior of velocity and have argued that both the changes in the stock of money and its velocity must be watched. In reviewing the observed movements of velocity following the recession of 1969-70, Arthur Burns pointed out that they first appeared to have offset and then to have reinforced the influence of money on income. He concluded that

Occurrences such as this are very common because the willingness to use the existing stock of money, expressed in its rate of tumover, is a highly dynamic force in economic life. ${ }^{3}$

He further concluded that

In short, what growth rate of the money supply is appropriate at any given time cannot be detemined simply by extrapolating past trends or by some preconceived arithmetical standard.4

The purpose of this article is to identify the major factors which influenced observed movements in velocity in the United States during the period from 1955 to 1973. Identification of these factors and the nature of their influence on observed movements in velocity, provides a partial basis for evaluating the evidence offered by some analysts that the response of income to a change in the money stock is not predictable.

First, observed movements in velocity in the period 1955 to 1973 are briefly discussed. Second, a model of

2Ibid., p. 676.

3Arthur F. Burns, "Letter on Monetary Policy," this Review (November 1973 ), p. 17.

4lbid, p. 18. His view is further elaborated in prepared testimony presented before the Senate Banking Committee, May 1, 1975. 


\section{Changes in Observed Income Velocity and Money Quorier-te-0uarter Compound Anaual Rates of Change}

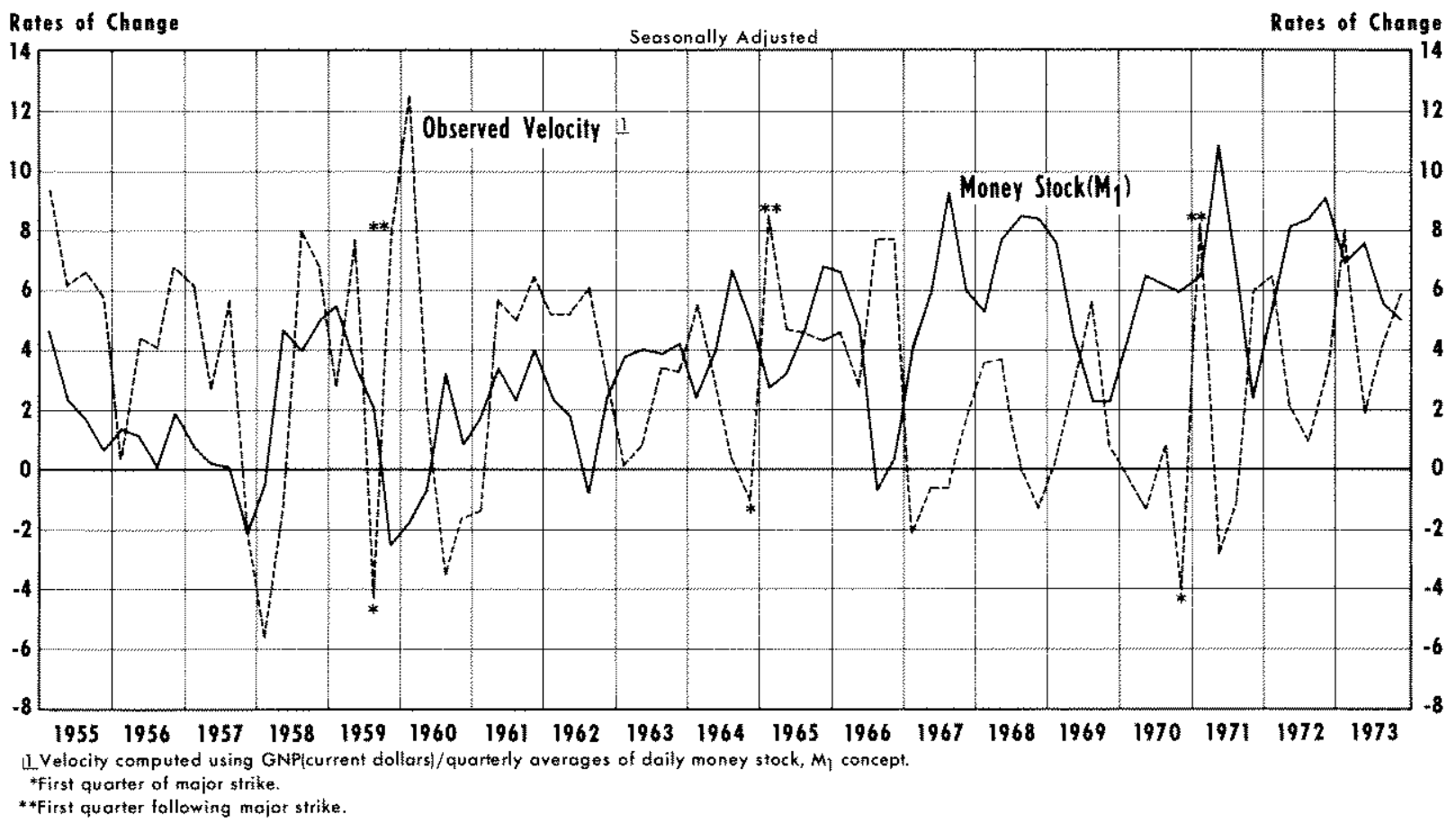

nominal income determination, which is used to identify the various influences on observed velocity, is summarized. Third, implications of the model for observed movements in velocity are given. The model is then used to explain various observed movements in velocity in the period under examination.

The results of this study lead to the conclusion that observed movements in velocity, taken alone, provide little useful evidence in the debate regarding the predictability of the response of income to a change in money. Another conclusion is that misunderstanding of the factors causing changes in observed velocity, and the inability to observe changes in desired money balances, could result in monetary policy actions which are unintentionally procyclical. In other words, the lack of reliable information regarding the utilization of money balances suggests that the growth in the stock of money should not be sharply expanded or contracted as a result of observations or expectations regarding short-run fluctuations in the income velocity of money.

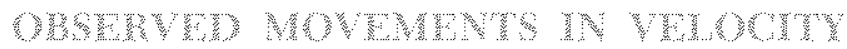

There are three general kinds of observed movements in velocity which have been cited as evidence that the response of income to a change in the money stock is not very predictable. ${ }^{5}$ These are (1) quarterto-quarter movements, (2) movements lasting a few quarters which appear to offset or reinforce the influence of a change in money on income, and (3) the trend growth of velocity.

The most frequently employed measure of velocity uses nominal GNP as the measure of nominal income and defines money as currency and demand deposits held by the nonbank public $\left(\mathrm{M}_{1}\right)$. Illustrations of observed movements in this measure of velocity are taken from the period 1955 to 1973.

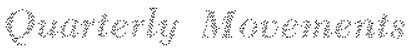

On a quarterly basis, observed movements in velocity have been very volatile. For example, from 1955 to 1973 quarterly changes in observed velocity, omiting quarters inftuenced by a major strike, varied be-

\footnotetext{
5For a discussion of these movements in velocity and their implications for monetary policy, see George Garvy and Martin $\mathrm{R}$. Blyn, The Velocity of Money (New York: Federal Reserve Bank of New York, 1969) pp. 78-94. AIso, see Sherman J. Maisel, Managing the Dollar (New York: W. W. Norton \& Company, Ine., 1973), pp. 273-276. For a more recent view, see R.E.D. Chase, "Velocity: Can It Be Ignored as a Monetary Variable," The Money Manager (June 30, 1975).
} 


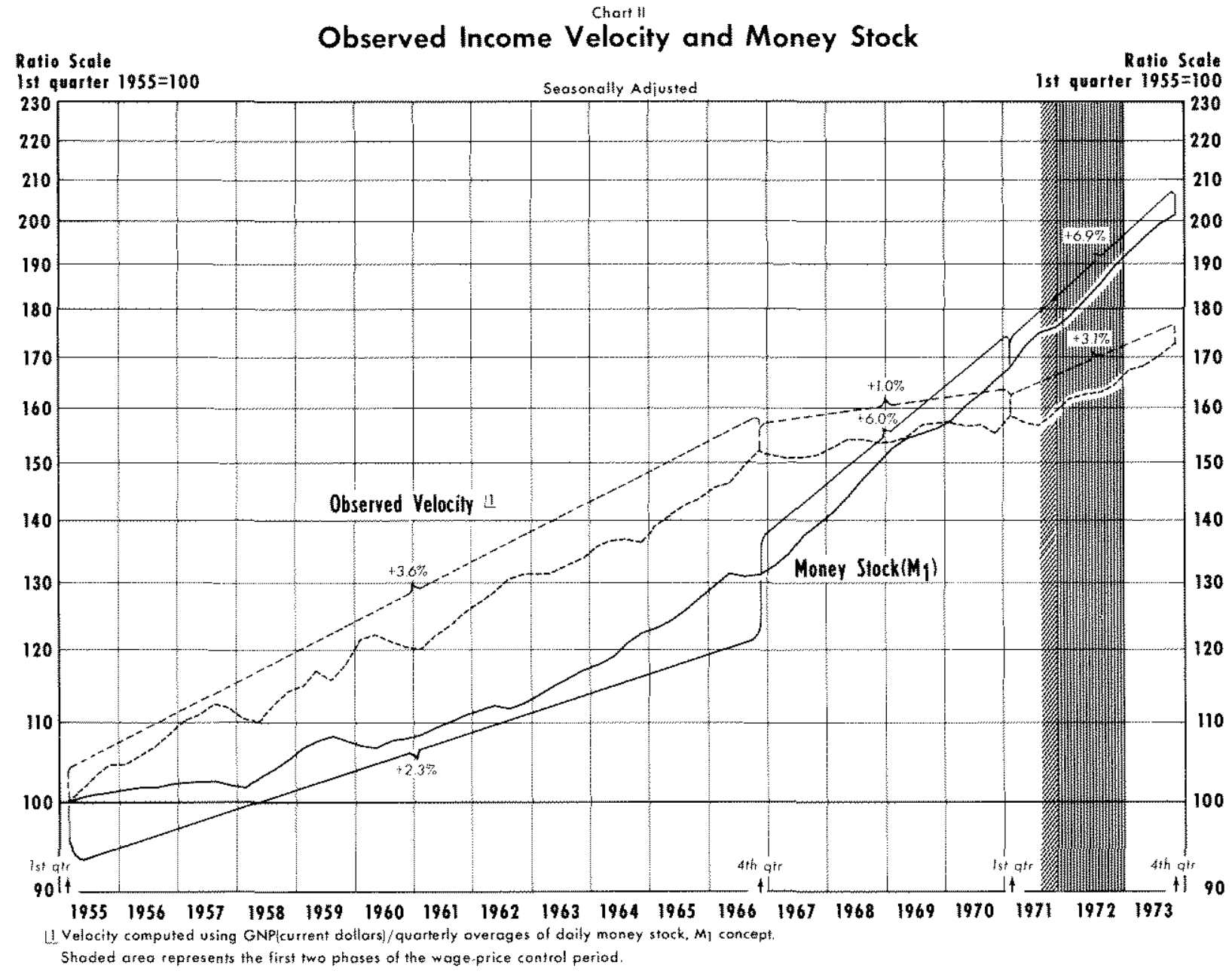

tween +12.5 and -5.6 percent, at annual rates (Chart I). Over this span of years the average of these changes in velocity, without regard to sign, was 3.9 percent.

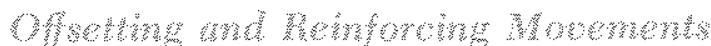

Frequently, changes in the growth of observed velocity have been in the opposite direction of changes in money growth for a few quarters. At other times, changes in the growth of observed velocity have been in the same direction as changes in money growth. The first case gives the appearance of offsetting the influence of the change in money on income; the second case gives the appearance of reinforcing this influence.

Arthur Burns cited the recovery experience from the recession of 1969-1970 as a case in point:
For example, the narrowly-defined money stock - that is, demand deposits plus currency in public circulation - grew by 5.7 percent between the fourth quarter of 1969 and the fourth quarter of 1970. But the turnover of money declined during that year, and the dollar value of GNP rose only 4.5 percent. In the following year, the growth rate of the money supply increased to 6.9 percent, but the turnover of money picked up briskly and the dollar value of GNP accelerated to 9.3 percent. The movement out of recession in 1970 into recovery in 1971 was thus closely related to the greater intensity in the use of money.

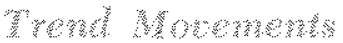

Observed velocity also exhibits trend movements lasting over a period of many years. Abrupt changes in the trend growth of observed velocity, however,

6Burns, p. 17. 
have occurred. For example, observed velocity grew at a 3.6 percent average annual rate from $\mathrm{I} / 1955$ to IV $/ 1966$, at a one percent annual rate to $1 / 1971$, and then at a 3.1 percent rate to IV/1973 (Chart II). ${ }^{i}$

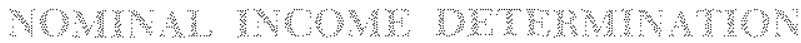

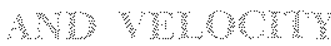

A monetary model of nominal income determination provides a basis for identifying the factors influencing observed movements in income velocity. The theoret. ical model is first summarized and then its empirical form is presented. The model of nominal income determination was developed in detail elsewhere. ${ }^{8} \mathrm{Em}$ pirical tests did not reject the theoretical model as an explanation of nominal income determination in the period I/1955 to IV/1973.

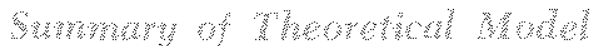

The model postulates that the change in the rate of change in spending by households and business firms for newly produced final goods and services from both domestic and foreign sources responds over time to the discrepancy between the rates of change in actual and desired money balances. Also, the rate of change in desired money balances is postulated to be positively related to the rate of change in perceived nominal income, and negatively related to the rates of change in the technical efficiency of the payments system (defined as the average amount of money balances technically required to conduct a given volume of nominal money payments) and in the short-term nominal interest rate.

Combining these postulates, the change in the rate of change in spending by households and business firms is positively related to the rates of change in money balances, in the technical efficiency of the payments system, and in the nominal short-term interest rate; it is negatively related to the rate of change in perceived income. The rate of change in nominal income is equal to the weighted sum of the

TFor a discussion regarding their inability to explain by conventional monetary theory the IV/1966 break in the trend of observed velocity, see Phillip Cagan and Amna I. Schwartz, "Has Growth of Money Substitutes Hindered Monetary Policy? , Journal of Money, Credit, and Banking (May 1975), pp. 142-143.

sLeonall C. Andersen, "A Monetary Model of Nominal Income Determination," this Retiew (June 1975), pp. 9-19. For a study of incone velocity using a Keynesian type model, see John M. Mason, "A Structural Study of Income Velocity of Circulation," Journal of Finance (September 1974) pp. 1077-86. Mason's study yields results similar to many of those in this article.

\section{Exhibit:}

\section{EMPIRICAL FORM OF THE MODEL}

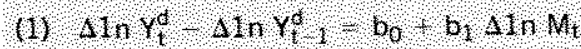

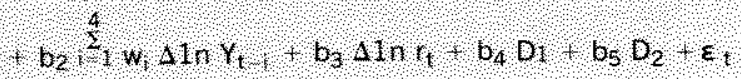

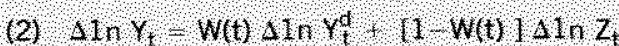

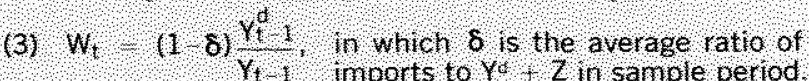

(4) $41 \cap V_{1}, 41, Y_{t}, 8 n \cap$

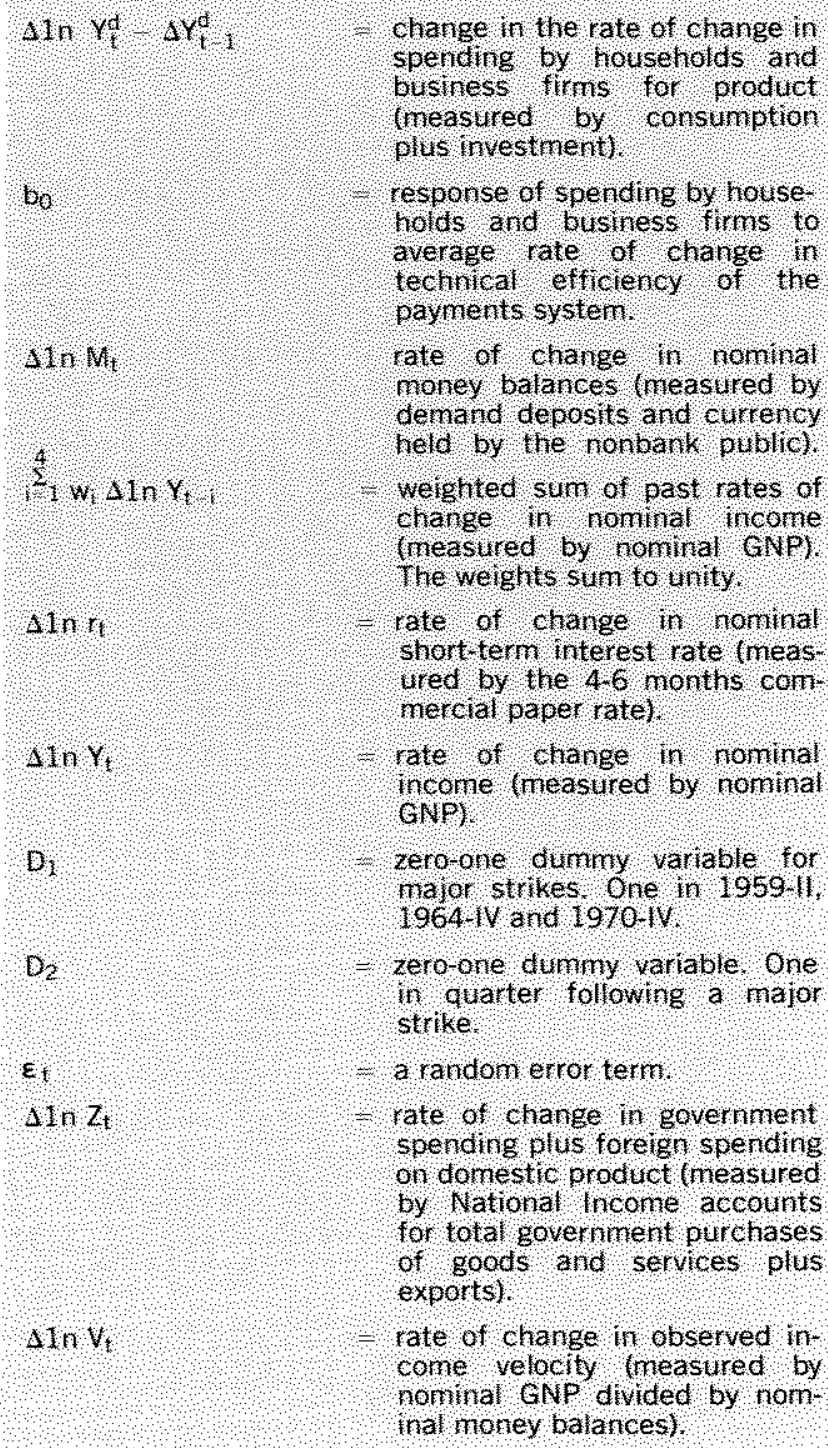

rates of change in spending by households and business firms, in spending by all units of government for product, and in foreign spending for domestic product.

Velocity is introduced into the model by an identity. The rate of change in observed velocity is equal to the rate of change in nominal income minus the 


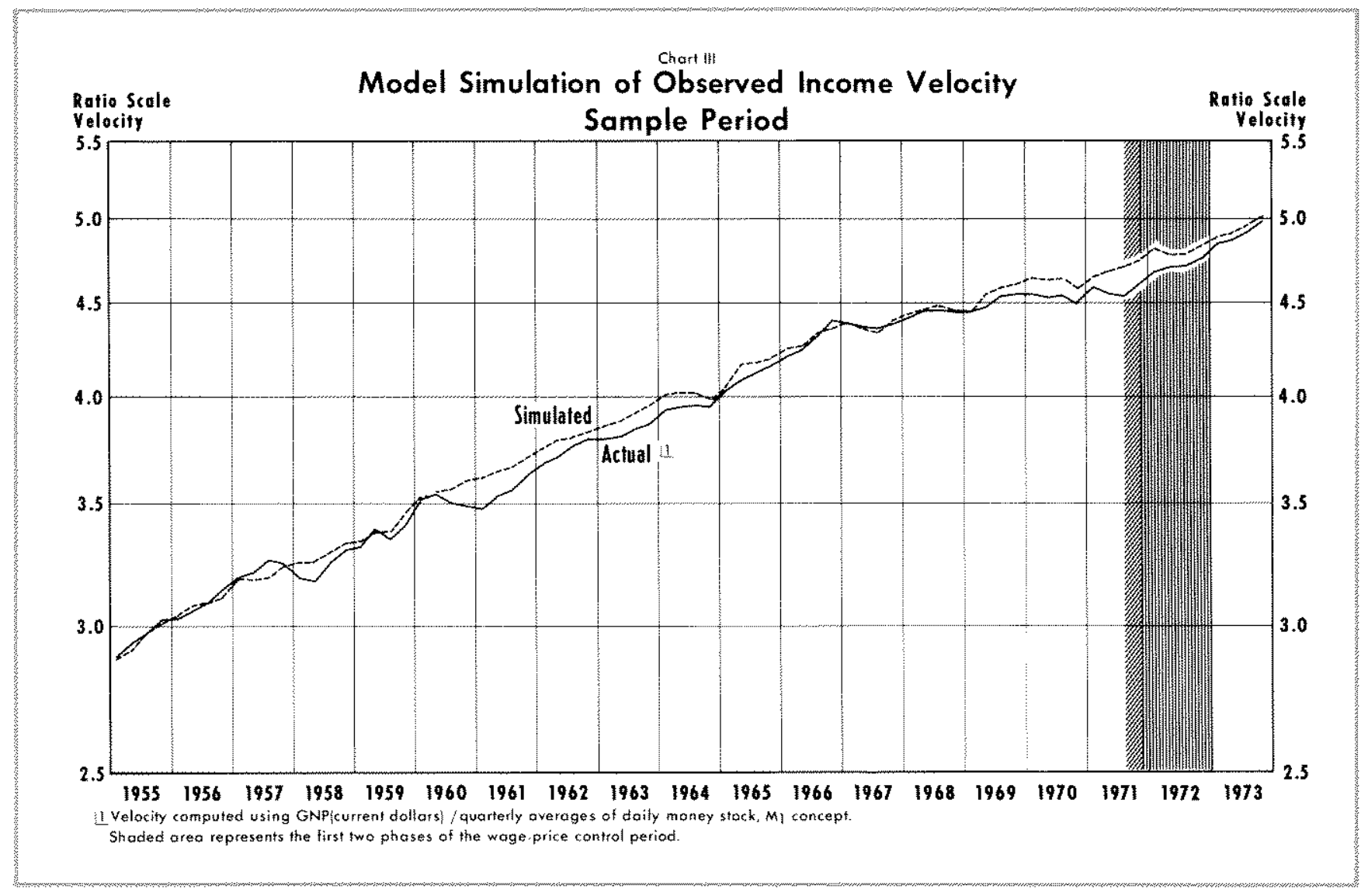

Table

Regression Results

Equation 11 , Exhblt

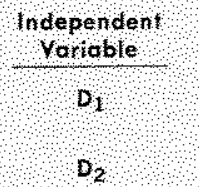

$\Delta$ in $M$

$\Delta 1 n$

$\Delta \mathrm{n} \mathrm{Y}_{\mathrm{I}}$

$\Delta \ln \mathrm{Y}_{2}$

$\Delta \mathrm{n}_{\mathrm{n}}$

$\Delta n_{1} \mathrm{l}_{4}$

Constant

$R^{2}$

SEE

ow
Enfrorad

Coeficient:

1,930

$(-3,744)$

2,380

(4.326)

701

$(45.27)$

020

$(2,83)$

0.792

$(-5,242)$

$-274$

$(-2,64)$

226

11846

3309

$(-2,739)$

1152

$(3.785)$

580

8.64

2030

Nunbers whbm porentieses are ot anefletents.

rate of change in nominal money balances. Observed income velocity is thus a residual.

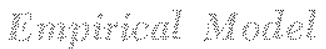

The parameters of the relationship which combines the two postulates regarding behavior of households and business firms are estimated by ordinary leastsquares, using quarterly data for the period $1 / 1955$ to IV $/ 1973 .^{9}$ It is assumed that the technical efficiency of the payments system increases, on average, at a constant rate. The rate of change in perceived income is treated as a weighted sum of past rates of change in nominal income. The equations of the empirical model are presented in Exhibit I, and the estimated coefficients of equation (1) are listed in Table $\mathrm{I}$.

Dynamic simulations of the model indicate the degree to which it tracks observed velocity in the sample period (Chart III). The root mean squared error of the quarterly levels of simulated velocity is 1.57 percent.

-See Andersen, "A Monetary Model of Nominal Income Determination," pp. 13-16. for specific details of development of the empirical form of the model. Rates of change are approximated by first differences of natural logarithms of the variables. 


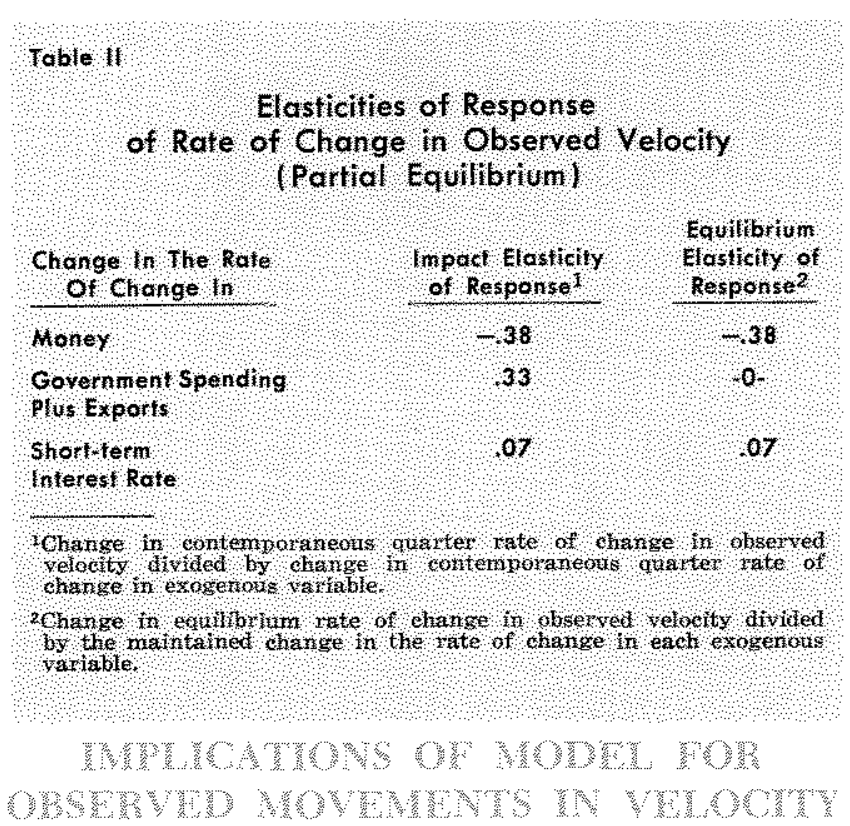

The implications of the model for observed movements in velocity are ascertained by dynamic simulations. In these simulations, the partial equilibrium response of the rate of change in income to changes in the various exogenous variables is determined first. ${ }^{\text {to }}$ Then, the velocity identity is used to determine the partial equilibrium response of the rate of change in observed velocity. Of special interest are the impact and equilibrium elasticities of response, the time path, and the length of time to achieve equilibrium.

Four simulation exercises are conducted. First, the rate of change in observed velocity resulting only from the average rate of change in the technical efficiency of the payments system in the sample period is simulated. The other three simulations measure the partial equilibrium response of the rate of change in observed velocity to maintained changes in the rate of change in money, in government expenditures plus exports, and in the short-term rate of interest. The magnitudes of changes in these three variables are drawn from the sample period. The elasticities of response are reported in Table II, and the time paths to equilibrium are shown in Charts IV-VI.

The simulation results are subject to two qualifications. No feed-back influences on the rate of change in velocity through induced interest rate changes are considered. Therefore, the following simulation results are only for the direct (partial equilibrium) responses of the rates of change in nominal income and observed velocity to changes in the three exogenous variables.

10 Since the model does not include an explanation of interest rate determination, it is a partial equilibrium model.

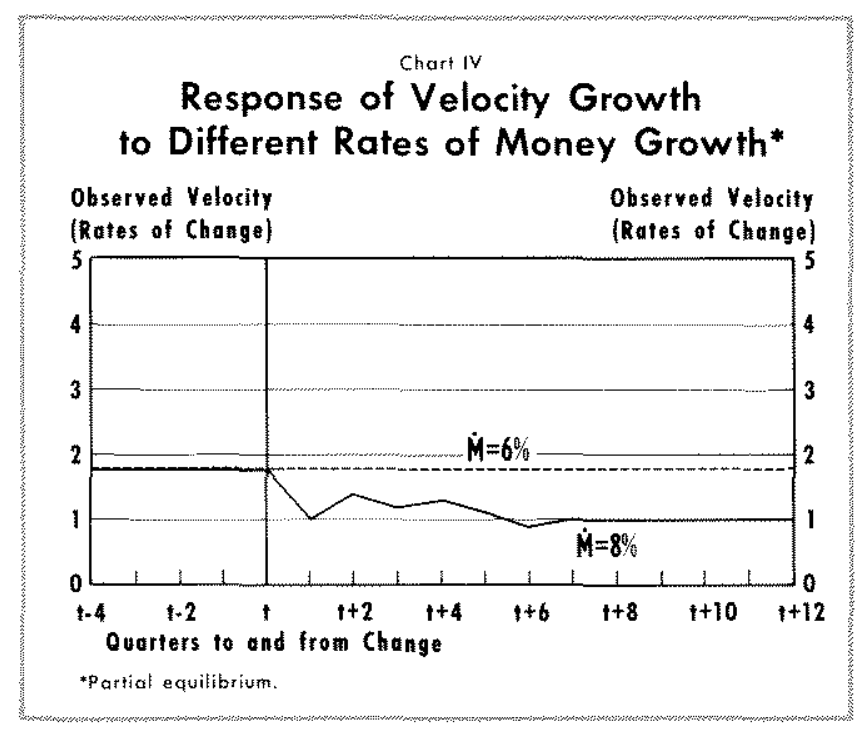

After the simulation results are presented, a qualitative assessment is made regarding the impact of possible feed-back influences. A second qualification is that the simulation results are only applicable to the experience within the sample period $1 / 1955$ to IV/1973.

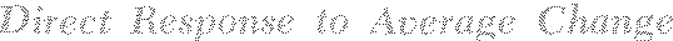

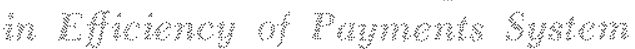

The rate of change in observed velocity resulting from only the average rate of change in the efficiency of the payments system in the sample period is measured by simulating the model with the rates of changes in the three exogenous variables set at zero. This simulation indicates that nominal income, and therefore, observed velocity, would have grown at a 4.1 percent annual rate if there were zero rates of change in money, in government spending plus exports, and in the short-term interest rate.

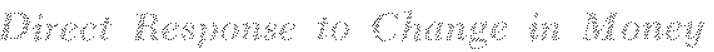 Crowers}

Two simulations of the direct response of the rate of change in observed velocity to a maintained change in the rate of change in money are performed, with the rates of change in the other two exogenous vari ables set at zero. The first one simulates the equilibrium rate of change with a 6 percent annual rate of change in money. The second one increases the rate of change in money from a 6 percent rate to an 8 percent rate. The simulation results are presented in Chart IV.

These simulations indicate that the equilibrium rate of change of observed velocity decreases when there is a maintained increase in the rate of change of money. 
The equilibrium elasticity of response is -0.38 (Table II). This result comes from the fact that the estimated elasticity of desired money balances with respect to perceived income is greater than unity. ${ }^{11}$ In equilibrium, with zero rates of change in the other exogenous variables, the annual rate of change in nominal income is equal to 4.1 percent plus the annual rate of change in money multiplied by the reciprocal of the elasticity of desired money balances with respect to perceived income. Since this elasticity is greater than unity, an increase in the rate of change in money produces a less than proportional change in the rate of change in income. Since the rate of change in observed velocity is defined as the difference between the rates of change in income and in money, the rate of change in observed velocity therefore $_{3}$ decreases.

\section{Dreet Response to Whage wh the rate

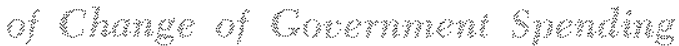

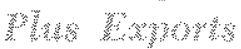

The equilibrium rate of change in observed velocity for a maintained 6 percent annual rate of increase in government spending plus exports, with changes in the other two exogenous variables set at zero, is reported in Chart $V$. The Chart also shows the results when the rate of change in government spending plus exports is reduced from a 6 percent rate of increase to a 4 percent rate of decrease.

These simulations indicate that a change in the rate of change in government spending plus exports exerts a significant short-run impact on the rate of change in observed velocity, but has no long-run effect (Table II). This follows from the dynamic property of the model in which an increase in the rate of change in government spending plus exports initially increases the rate of change in income and, hence, in observed velocity. But, subsequently, the rate of change in desired money balances increases, producing a decrease in the rate of change in spending by households and business firms. In equilibrium, the rate of change in spending by households and business firms has been reduced to the extent that the initial increase in the

11 Ibid., p. 19. The estimated elasticity is 1.6. In equilibrium,

$$
\begin{aligned}
& \Delta \ln Y_{t}=4.1+\frac{1}{\alpha} \Delta \ln M_{t} \\
& \Delta \ln V_{t}=4.1+\left(\frac{1}{\alpha}-1\right) \Delta \ln M_{t}
\end{aligned}
$$

The symbol " $\alpha$ " is the elasticity of desired money balances with regard to perceived income. If $\alpha=1$, the usual assumption in monetary theory, there is no equilibrium response of the growth of observed velocity to a change in the growth of money, other factors held constant. If $\alpha<1$, there is a positive response, and if $\alpha>1$, there is a regative response.

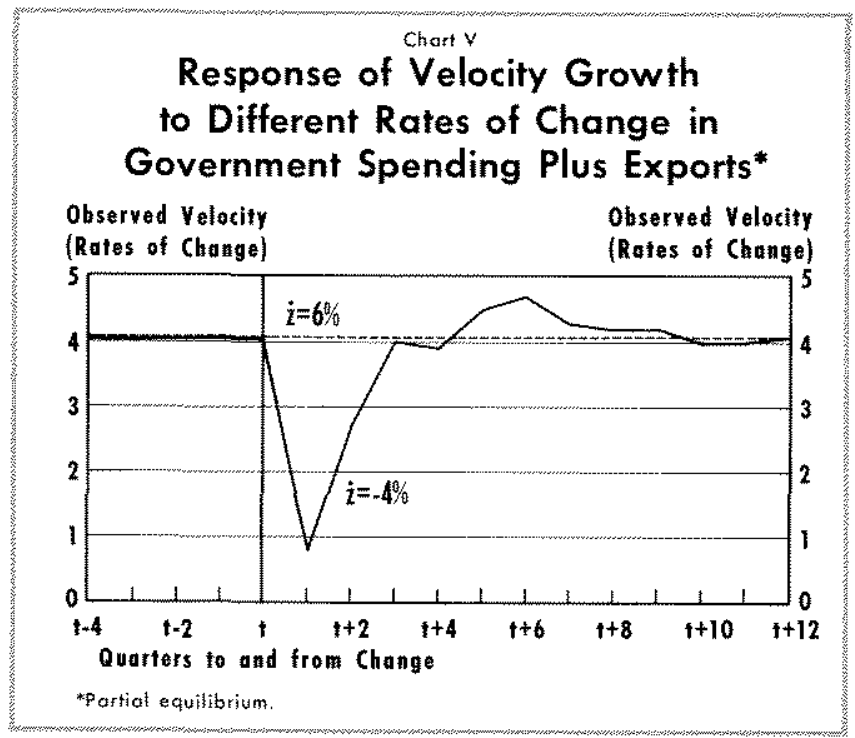

rate of change in nominal income has been completely offset. $^{12}$ Since there is no effect on the equilibrium rate of change in income, there is also no effect on observed velocity.

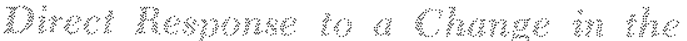

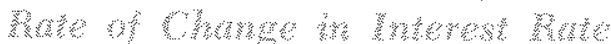

The equilibrium rate of change in observed velocity for a 3 percent annual rate of increase in the interest rate, with changes in the other two exogenous variables set at zero, is reported in Chart VI. The Chart also shows the results when the rate of change in the interest rate changes from the previous 3 percent annual rate of increase to a 9 percent annual rate of decrease.

These simulations indicate that the rate of change in observed velocity is little influenced by a maintained change in the rate of change in the interest rate, unless such changes are exceedingly large. The equilibrium elasticity of response of observed velocity to a change in the rate of change in the interest rate is very small (Table II). This results from an exceedingly small (.028) estimated elasticity of desired money balances with respect to the interest rate.

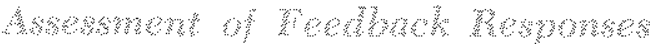

The simulations in Charts IV and $V$ are for the direct (partial equilibrium) response of the rate of change in observed velocity to changes in the rate of change in money and in government spending plus exports. The total response for each simulation would also include the indirect response to induced changes

127 bid., p. 13 . 


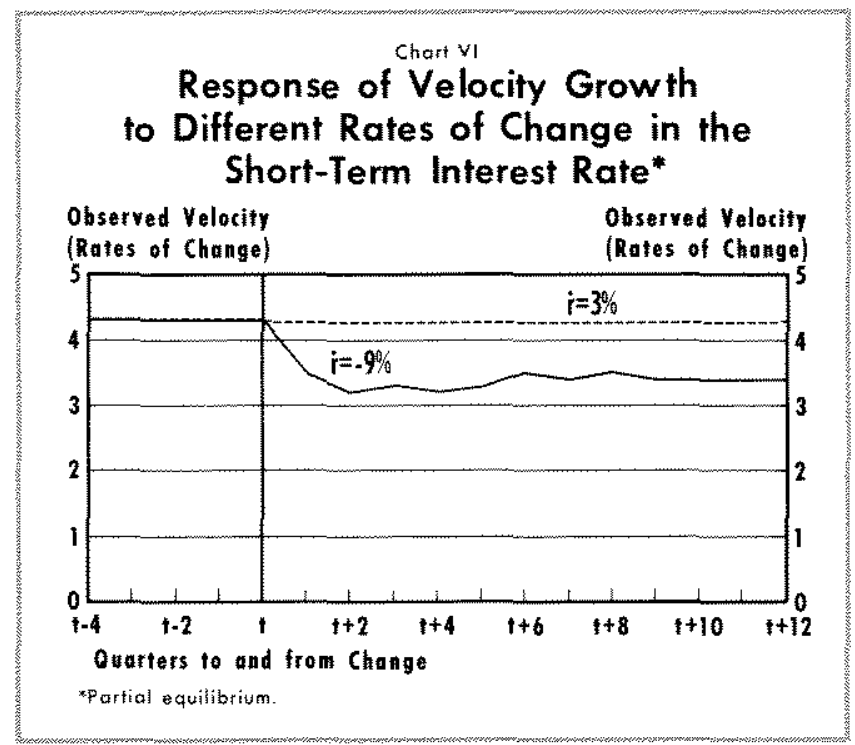

in the rate of change in the short-term interest rate, or in the other variables previously treated as exogenous. Though the model does not provide an estimate of these indirect responses, a qualitative assessment of some of them can be made. This section analyzes two cases - an increase in the rate of change in money and a decrease in the rate of change in government spending.

There is a theory accepted by many economists that, starting from dynamic equilibrium, a maintained increase in the rate of change in money first decreases the nominal interest rate which, according to the model, increases the rate of change in desired money balances and thereby reduces the rate of change in nominal income. As a result, the rate of change in observed velocity would be less than that initially attributed to faster money growth in Chart IV. Then, according to this theory, the faster growth of nominal income increases the nominal interest rate during the next few quarters, thereby reducing the rate of change in desired money balances. This increases the rate of change in nominal income growth, and, hence, of observed velocity, above that reported in Chart IV. Subsequently, both the actual rate of inflation and the expected rate of inflation increase, which tends to increase further the nominal interest rate. As a result, there is an additional increase in the rate of change in nominal income, and, therefore, the rate of change in observed velocity will be greater than that reported in Chart IV.

In equilibrium, when the expected rate of inflation equals the actual rate, the nominal interest rate remains constant, the rate of change in nominal income is constant, and, thus, the rate of change in observed velocity no longer changes. In the transition to the new (lower) equilibrium growth rate of velocity, however, its rate of change is less than the initial response indicated in the simulations (Chart IV) but is subsequently higher for several quarters.

Since the rate of change in money and the interest rate are held constant, the simulation of the direct response of observed velocity to a decrease in the rate of change in government spending implies that a slower rate of change in government spending is matched by reduced tax collections. In the case of a reduction in the rate of change in government spending and no change in taxes, a government surplus would be generated. If the surplus were used to retire outstanding debt, the nominal interest rate would decrease and the rate of change in nominal income, and, hence, in observed velocity, would be smaller than that reported in Chart $\mathrm{V}$ as long as the nominal interest rate decreases. If debt is not retired as a result of the budget surplus, growth of money would be reduced as government adds to its cash balances, which are not included in the money stock. In this case, growth of nominal income would be smaller and, as a result, observed velocity growth would also be smaller than that reported in Chart $\mathrm{V}$ as long as the surplus exists.

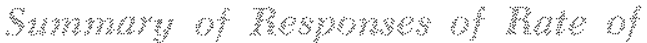

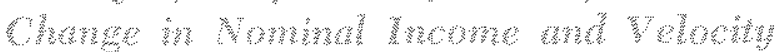

The simulation results (partial equilibrium analysis) indicate that in the sample period the "basic" trend growth rate (a 4.1 percent annual rate) of nominal income, and, therefore, observed velocity, is determined by the average long-run rate of increase in the efficiency of the payments system. The observed trend growth rate of velocity in the sample period is 4.1 percent (annual rate) minus 0.38 times the trend growth of money (anmual rate) plus 0.07 times a maintained rate of change (annual rate) in the interest rate. The trend rate of change in government spending plus exports has no direct influence on the trend rate of change in nominal income and, consequently, has no direct influence on the trend in observed velocity.

Short-run changes in the rate of change in money, in government spending plus exports, and in the short-term interest rate exert a significant impact on the short-run rate of change in nominal income and, hence, in observed velocity. In addition, since it takes about ten quarters to move from one equilibrium rate of change to another, initial conditions in the form of 
lagged rates of change in the three exogenous variables over the ten preceding quarters have an important influence on short-run changes in the rate of change in observed velocity.

These short-run responses of the rate of change in observed velocity result from two properties of the model. The change in the rate of change in nominal spending by households and business firms responds over time to a discrepancy between the rates of change in actual and desired money balances, and the rate of change in perceived income responds to lagged rates of change in nominal income.

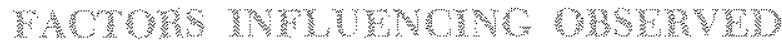

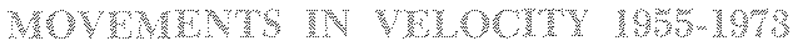

The implications of the model are used to ascertain the factors influencing observed movements in velocity in the 1955-73 period. Attention is focused on the special instances of observed velocity movements mentioned earlier in the article, which have been cited by some analysts as evidence that the response of income to a change in money is not very predictable.

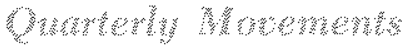

A considerable part of the current-quarter variability in the rate of change in observed velocity shown in Chart I can be attributed to current-quarter changes in the rates of change in money, in government spending plus exports, and in the interest rate that occurred in the sample period. Furthermore, current-quarter variability in the rate of change in observed velocity results from variability in the rates of change in the three exogenous variables in previous quarters.

The simulation exercises indicate that the changes in the current-quarter rate of change in money result in an opposite change in the current-quarter rate of change in observed velocity (Chart IV). This result is due to the property of the model that the rate of change in nominal spending by households and business firms responds only over time to a discrepancy between the rates of change in actual and desired money balances. For example, starting from equilibrium, an increase in the rate of change in actual money balances produces a positive discrepancy between the rates of change in actual and desired money balances. As a result the current-quarter rate of change in nominal spending by households and business firms (and, hence, in nominal income) increases, but not by as much as the increase in the rate of change in money. Consequently, the current-quarter rate of change in observed velocity decreases.

In addition, changes in the current-quarter rate of change in government spending plus exports, or in the interest rate, result directly in similar changes in the current-quarter rate of change in nominal income and, hence, in observed velocity (Charts V and VI). Thus, with no change in the current-quarter rate of change in money, a current-quarter decrease in the rate of change in government spending plus exports, or in the interest rate, would result in a decrease in the currentquarter rate of change in observed velocity.

Also, two important properties of the model are that the rate of change in desired money balances responds to lagged rates of change in nominal income and that the rate of change in spending by households and business firms responds over time to a discrepancy between the rates of change in actual and desired money balances. Consequently, even with no current-quarter changes in any of the three exogenous variables, the current-quarter rate of change in observed velocity changes as long as the model is not in equilibrium. In such a case, the current-quarter rate of change in observed velocity reflects the response of income to previous changes in the rates of change in money, in government spending plus exports, and in the interest rate.

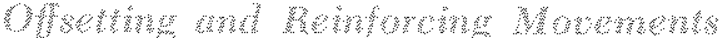

It has been argued that changes in the rate of change in observed velocity over a few quarters at times offset the influence of a change in the rate of change in money on income, and at other times augment this influence. The simulation results (Chart IV) indicate that an increase in the rate of change in money, maintained for two quarters, decreases the rate of change in observed velocity markedly in the contemporaneous quarter, giving the appearance of an offsetting movement. Then, the rate of change in observed velocity rises considerably in the next quarter, giving the appearance of a reinforcing movement. Moreover, a pronounced change in the rate of change in money maintained over a few quarters tends to change the rate of change in observed velocity in an opposite direction (Chart IV). In addition, short-run accelerations and decelerations in the rates of change in government spending plus exports and in the interest rate, or the occurrence of a major strike, also can cause a growth of observed velocity which is opposite to, or in the same direction as, the growth of money (see Charts V and VI). 
Consider the earlier analysis where it was alleged that a decrease in observed velocity in 1970 offset the influence of faster money growth on income in that year, and that an increase in observed velocity augmented its influence in 1971 . These movements in observed velocity, however, can be largely explained by actual movements in money and by the occurrence of a major strike at the end of 1970 .

A sharp deceleration in money growth occurred in 1969 , with money growing at a 2.3 percent annual rate during the second half of that year, compared with a 7.7 percent average annual rate in 1967 and 1968. Such a deceleration in money growth, according to the results of this study, would lead to an increase in velocity growth, which did happen in 1969 - observed velocity grew 2.3 percent, compared with an increase of 1.5 percent in 1968. Subsequently, money growth increased sharply to a 5.7 percent annual rate during 1970 and there was an auto strike in the fourth quar. ter; observed velocity decreased at a 1.2 percent annual rate, a movement which is consistent with the results of this study. Much of the observed acceleration of velocity growth in 1971, measured from IV/1970 to IV/1971, which appeared to have augmented the influence of money on income, reflected the recovery of income (and hence, observed velocity) following the auto strike in the last quarter of 1970.

Thus, much of what appeared to be an offsetting movement in growth of observed velocity in 1970 reflected the influence of the simultaneous increase in the growth of money and the auto strike. The aug. menting movement in 1971 reflected the recovery from the auto strike and the lagged response of income to the earlier more rapid monetary growth.

\section{Whages brend wroth}

Some analysts cite the breaks in the trend growth of observed velocity after 1966 (Chart II) as evidence of a structural change in the money demand function. A test of the hypothesis of such a structural change was made, and the hypothesis was rejected. ${ }^{13}$ Simulation of the model (Chart III) indicates that the breaks in the trend of velocity growth can be largely explained by behavioral variables, rather than "structural change".

The model simulation projects a 3.6 percent annual rate of increase in observed velocity from I/1955 to IV $/ 1966$, the same as the actual increase. From

13 Ibid., p. 18.
IV $/ 1966$ to $1 / 1971$, the simulation projects a deceleration to a 1.5 percent rate of increase, compared with an actual 1.0 percent rate of increase. From I/1971 to IV $/ 1973$, an acceleration to a 2.7 percent rate of increase is projected, which compares with an actual rate of 3.1 percent.

Changes in the trend growth of observed velocity, according to the results of this study, reflect mainly changes in the trend growth of money. In addition, a prolonged change in the rate of change in the shortterm interest rate, which is large, or in the rate of change in government spending plus exports, also exerts a temporary influence on the trend growth of observed velocity.

Simulations of the model (Chart IV) indicate, in partial equilibrium analysis, that an increase in the growth rate of money which is maintained for over ten quarters decreases the growth rate of observed velocity, and this decrease persists until there is another maintained change in the growth rate of money. Hence, the model indicates, in partial equilibrium analysis, that changes in the trend growth rate of observed velocity are inversely related to changes in the trend growth rate of money.

An examination of money growth from 1955 to 1973 (Chart II) in conjunction with the results of this study leads to the conclusion that the break in the trend of velocity observed from IV/1966 to $\mathrm{I} / 1971$ reflected mainly an acceleration in the growth of money during that period. The growth of money was at a 2.3 percent annual rate from $\mathrm{I} / 1955$ to $\mathrm{IV} / 1966$. Ignoring changes in the rates of change in government spending plus exports and in the interest rate, this projects a trend growth of observed velocity at a 3.2 percent annual rate, compared with the actual trend rate of 3.6 percent. Money then grew at a 6 percent anmual rate to $\mathrm{I} / 1971$; this projects a deceleration to a 1.8 percent trend growth of observed velocity, compared with an actual rate of 1.0 percent.

Changes in the trend growth of money by themselves, however, cannot account for the acceleration of observed velocity growth to a 3.1 percent annual rate from $\mathrm{I} / 1971$ to $\mathrm{IV} / 1973$. During that period, money growth accelerated to a 6.9 percent rate, which, by itself, would imply a further deceleration of observed velocity growth to a 1.6 percent rate. Accelerations in the rate of change in government spending plus exports and in the interest rate, however, are consistent with the acceleration in growth of observed velocity. Government spending plus exports rose at a 15 percent annual rate from IV/1971 to IV/1973, com- 
pared with a 6 percent rate of increase in the preceding ten quarters. The short-term interest rate rose at a 15 percent annual rate from $\mathrm{I} / 1972$ to $\mathrm{IV} / 1973$, compared with an 8 percent rate of decrease in the preceding ten quarters. Both of these changes, according to the results of this study, would tend to increase substantially, but only temporarily, the growth rate of observed velocity.

\section{Whan}

The results of this study demonstrate that neither short-rum nor long-rum movements in observed velocity, taken alone, provide evidence in the debate regarding the predictability of the response of income to a change in money growth. In addition, the conclusion is reached that using changes in observed velocity alone in a naive manner, without information regarding the causes of the changes, in formulating a targeted rate of money growth could lead to undesired changes in the growth of nominal income. ${ }^{14}$

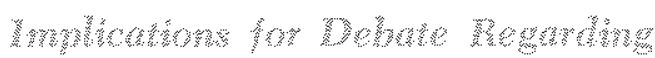

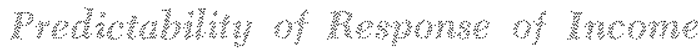 ke know}

The results of this study indicate that growth of observed velocity reflects factors influencing growth of desired money balances, changes in growth of the money stock, and changes in growth of government spending plus exports. Among these, there are three major influences: a basic trend rate of growth determined by the response of desired money balances to the average change over time in the efficiency of the payments system; deviations from this basic trend rate reflecting changes in the rates of change in the growth of money and of government spending plus exports; and initial conditions in the form of changes in past rates of change in these latter two variables over the previous ten quarters. When changes in the rates of change in the interest rate are extremely large, they also influence significantly changes in the rate of observed velocity growth.

These results thus indicate that observed movements in the growth of velocity, taken alone, yield ittle useful information regarding growth of desired money balances, in either the short run or the long run. Much of the observed movement in the growth rate of

14It should be pointed out that the results of this study reflect the movements in the variables in the sample period 1955 to 1973. Specific conclusions drawn from these results, therefore, are applicable to the institutional setting of that period and to movements in the variables withir their observed ranges. velocity reflects the adjustment process of the rate of change in nominal income to a discrepancy between the rates of change in desired and actual money balances. Consequently, variations in the rate of change in observed velocity reflect the response of the rate of change in income to both changes in the rate of change in money and changes in the rate of change in desired money balances.

Changes in desired money balances have been alleged by some analysts to produce a very unpredictable response of the rate of change in nominal income to a change in the rate of change in money. However, since this study indicates that observed changes in the rates of change in velocity reflect the influence of changes in the rates of change in desired money bal ances and in money, it is concluded that the behavior of observed velocity, by itself, provides little evidence regarding the predictability of the response of the rate of change in income to a change in the rate of money growth. Moreover, changes in the rate of change in nominal income in response to changes in the rate of change in govermment spending plus exports tend to obscure the observed response of income to changes in the rate of change in money.

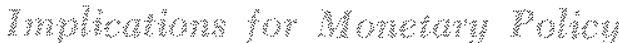

It is further concluded that taking observed growth of velocity into consideration in the planning of a course of money growth, without taking into consideration the response of observed velocity growth to changes in growth of money and in growth of government spending plus exports, can lead to perverse results. For example, if the immediate decrease in observed velocity growth in response to a sharp increase in the rate of money growth is viewed as an increase in growth of desired money balances, and if an attempt is made to offset this by faster money growth in the next period, income would subsequently grow faster than planned. Or, if the fall in the trend growth of observed velocity in response to a maintained acceleration in money growth is viewed as a permanent increase in growth of desired money balances, an attempt to compensate for this by increasing money growth would lead subsequently to an acceleration of income growth.

Also, failure to take into consideration the influence of other exogenous factors on observed velocity growth can lead to perverse results, For example, if a temporary increase in growth of observed velocity resulting from an acceleration in growth of government spending is interpreted as a decrease in the 
growth of desired money balances, efforts to offset this supposed influence on income by a slower growth of money can lead to an undesired slowing in the growth of income.

Another implication is that a more stable growth of money would produce a more stable growth of observed velocity. This is in marked contrast to the views of some analysts that in seeking to control movements in nominal income, growth of money would have to be highly volatile in order to offset observed movements in velocity. ${ }^{15}$

15For example, see Chase, "Velocity: Can It Be Ignored as a Monetary Variable," p. I5. Chase argues that in order to control economic activity. "Perhaps the answer is that it is not enough to control money supply alone but that velocity must also be controlled and its swings damped."

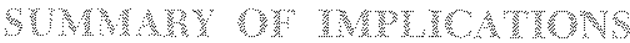

In summary, the use of observed changes in velocity growth, by themselves, in conducting monetary policy is often misleading and potentially dangerous. $\mathrm{Ob}$ served velocity changes are frequently a misleading indicator of changes in the growth of desired money balances. Moreover, taking into consideration observed changes in velocity growth in planning a path of monetary expansion, without separating its response to factors influencing growth of desired money balances from its response to changes in the growth of money or its response to changes in other exogenous factors, could lead to undesired movements in income.

This article is available as Reprint No. 92.

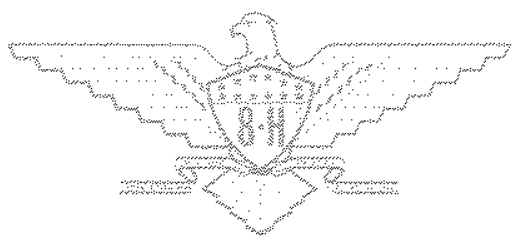

